\title{
DOI: 10.7596/taksad.v5i1.515
}

\section{Sosyo-Kültürel Açıdan Kelâm ve Hadis İlimlerinde Epistemoloji*}

\author{
Harun Çağlayan ${ }^{1}$
}

\section{Öz}

Kelâm ilminde bilgi kaynağı olarak akla önem verilirken, Hadis ilminde habere önem verilir. Bu yaklaşımın temel nedeni, Kelâm ilminin İslâmî öğretinin savunuculuğunu ve propagandasını yapan aklî bir ilim olmasıdır. Nakli bir ilim olarak Hadis ilmi ise Müslüman toplum yaşamında önemli bir konuma sahip Sünnet'in tespitiyle ilgilenmektedir. Bu farkl11ıktan dolayı, tarihsel süreç içerisinde Kelâm ve Hadis ilimleri birbirine alternatif veya rakip disiplin gibi algılanmıştır. Bu çalışmada, Müslüman toplumların içinde bulunduğu sosyo-kültürel dinamikler ve eğitim politikaları göz önünde bulundurularak, Kelâm ve Hadis'in epistemolojik yaklaşım tarzını belirleyen faktörlerin neler olduğuna temas edilecektir. Çalışma üç bölümden oluşmaktadır. Birinci bölümde İslam'da eğitim ve eğitim kurumları konularına temas edilmiştir. İkinci bölümde eğitsel açıdan hadis ve kelam ilimleri ile ilgili meseleler ele alınmıştır. Üçüncü bölümde ise epistemolojik açıdan hadis ve kelam ilimlerinde haber konusu incelenmiştir.

Anahtar Kelimeler: Kelâm, Hadis, Haber, Medrese, Mezhepler, Eğitim, Bilgi Felsefesi.

\footnotetext{
* Bu makale Çankırı/ 08 Eylül 2012, Çankırı Belediyesi ve Samsun Ondokuz Mayıs Üniversitesi, Anadolu'nun İslamlaşma Sürecinde Daru'l Hadisler Sempozyumu'nda “Medrese Eğitiminde Hadis ve Kelâm İlimlerinin Epistemolojik Yaklaşımlarının Kültürel Kökenleri”, ismiyle sunulan tebliğin genişletilmiş halidir. ${ }^{1}$ Yrd. Doç. Dr., Kırıkkale Üniversitesi İslami İlimler Fakültesi, caglayanharun@gmail.com
} 


\title{
The Epistemology in the Sciences of Hadith and Kalam From the Perspective of Socio-Cultural Context
}

\begin{abstract}
The reason is an important source of information in the science of Kalam while the report (khabar) is an important source in the science of Hadith. The nature of these sciences is the main reason of this dichotomy. While Kalam defends and promotes Islamic doctrine, Hadith interests locating the deeds of the prophet (sunnah). Therefore, the sciences of Kalam and Hadith had been perceived as alternative or opponent disciplines to each other through the Muslim history. This study examines determining factors of epistemological approach of Kalam and Hadith by considering socio-cultural dynamics and educational policies of Muslim societies. The article consists of three chapters. The first chapter deals with the Islamic education and institutes. The second chapter handles educational issues related with the sciences of hadith and kalam. The last chapter examines the topic of "khabar (report)" in the sciences of Hadith and Kalam with an epistemological point of view.
\end{abstract}

Keywords: Kalam, hadith, khabar, reason, Islamic education, Islamic doctrine, madrasa, mazahib.

\section{Giriş}

Müslüman toplumlarda eğitim ve öğretim çalıșmaları, tarihsel süreç içerisinde her dönemin kendine özgü şartlarına göre bir gelişim seyri takip etmiştir. Vahyin ilk inzal olmaya başladığı dönemlerde evlerde başlayan eğitim faaliyetleri, daha sonraları ibadethane ve çevresinde gelişerek kurumsal bir yapıya bürünmüştür. İslâm peygamberi Hz. Muhammed'in önderliğinde başlatılan eğitim çalışmalarının masrafları, ilk dönemlerden itibaren resmi kanallardan karşılanmaya başlamış (Buhârî, Rikak: 17) ve tüm işleri ilimle meşgul olmak olan (Ebû Dâvud, Büyû': 36) Ashab-1 Suffe gibi yapıların 
doğmasına neden olmuştur (İbn Sa'd, ts: I/255, 256). Hz. Muhammed'in eğitim alanındaki bu uygulamalarının ilerleyen süreç içerisinde vahiy tarafından onaylanmış olması, ${ }^{2}$ eğitimin önemi ve geliştirilmesi açısından oldukça teşvik edici olmuştur. Ashab-1 Suffe'nin önemi, ilk Müslüman neslin ebedi âleme irtihalini müteakip, Mescid-i Nebevi etrafındaki müzakerelerde oynadıkları rol göz önünde bulundurulduğunda daha da iyi anlaşılmaktadır. Çünkü Kur'an eğitimi ve Hadis müzakeresi şeklinde ilmi faaliyetlerde bulunan Ashab-1 Suffe'nin ilmî kazanımları daha sonraki süreç içerisinde, ilimlerin tedvin ve tasnifinde yeri doldurulamaz bir görevi yerine getirmiştir (Yazır, 1979: II/940). Nitekim İslamî literatürde sıklıkla kendilerinden bahsedilen sahabenin Ashab-1 Suffe'den olması, İslâm peygamberinin eğitim konusundaki ileri görüşlülüğünün bir göstergesi olarak değerlendirilebilir (İbn Sa'd, ts: I/255, 256).

\section{Kurumsal Eğitim Çalışmaları}

İslam medeniyetinin dünya eğitim çalışmalarına en önemli katkısının tamamen kendi imkânlarıyla geliştirmiş oldukları medrese eğitim sistemi olduğunu söylersek abartmış olmayız. Medrese kelimesinin lügat manası, ders verilen yer, tedrisat mekânı ve ilimlerin tahsil edildiği bina şeklindedir (Türk Dil Kurumu [TDK], 1998: 509, 1361; Milli Eğitim Bakanlığı [MEB], 1995: II/1926). De-Ra-Se kök fiilinin ism-i mekân formundaki bu özel kullanımına ek olarak kelime, bir şeyin kendisinin silinip gitmesine rağmen izinin veya işaretinin kalması anlamına da gelmektedir. Aynı şekilde bilginin tedris edilerek zihinde aktarılması için de "De-Ra-Se" fiili kullanılır (İbn Manzûr, ts: 1359, 1360; elİsfehânî, ts: 167). Bu açıdan fiil, daha çok ders almak, ilim tahsil etmek, bilgi öğrenmek, bir mesele hakkında etraflı bilgi edinme ameliyesi gibi eğitim ve öğretim faaliyetleriyle ilgilidir. (TDK, 1998: 508; MEB, 1995: I/631). Nitekim kelimenin Kur’an'da kullanıldığ1 anlam aralığı da bu anlam ile uyumludur (Abdulbâkî, 1945: 256). Kelime, zaman içerisinde özel bir kullanıma bürünerek, öğrencilerin sistemli bir şekilde ilim tahsil ettikleri eğitim kurumlarını ifade etmeye başlamıştır (Türkiye Diyanet Vakfı [DİA] 1998: XXVIII/323).

\footnotetext{
2 "Sadakalarınızı, kendilerini Allah yoluna adayıp yeryüzünde dolaşamayanlara; hayâlarından dolayı, kendilerini tanımayanların zengin sandıkları yoksullara verin" (el-Bakara Sûresi, 2/273). İlgili ayetin Ashâb-1 Suffe hakkında indirildiği rivayet edilir (el-Kurtubî, 1427/2006: III/340).
} 
Fetihler ve sosyo-kültürel alandaki gelişmelere bağlı olarak İslâm medeniyetinin kendisini çevreleyen coğrafyada ciddi bir alternatifinin kalmaması, Müslüman toplumların eğitimin faaliyetlerinde bir güvene ve rahatlamaya neden olmuştur. Ancak daha sonraki dönemlerde Müslüman dünyasının kendi içinde bazı siyasi çevrelerin eğitimi bir silah gibi kullanma girişimleri, eğitim mantığının yapısında ve metodunda birtakım anlayış değişikliklerine neden olmuştur. Bu değişikliklerin en köklü olanı, Müslüman eğitim sisteminin amaç, kapsam ve metotlarının sistematik bir düzen içerisinde ele alınmaya başlandığı Kurumsal Medrese Geleneği'nin gelişimidir (Kafesoğlu, 1997: 389). Müslüman toplumların eğitim kurumları olan medreselerin eğitim anlayışları, ders programları, vakıf geleneği ve mimarisi göz önüne alındığında, tümüyle İslâm kültürüne özgün eğitim merkezleri olduğunu rahatlıkla söyleyebiliriz (DİA, 1998: XXVIII/323). İlk medrese oluşumları hakkında farklı iddialar olmakla birlikte (Çelebi, 1983: 41) ilk sistemli ve resmi medrese yapılanmasının Büyük Selçuklu Devleti zamanında "Nizamiye Medreseleri” adı altında ortaya çıktığını söylemek mümkündür (Kafesoğlu, 1997: 390).

Bilgeliği ve idareciliğiyle meşhur Ebu Alî el-Hasan et-Tûsî Nizamülmülk (ö.485\1092) tarafından en sistemlisi Bağdat'ta olmak üzere birçok şehirde değişik niteliklerle inşa ettirilen Nizamiye Medreseleri, birçok yönden İslam eğitim ve öğretim tarihinde ilklere imza atmıştır. Nizamiye medreselerinin en meşhuru, Bağdat Nizamiye Medresesi'dir. Nizamiye Medreseleri, siyasal ve toplumsal başarılarına bağlı olarak gittikçe önem kazanarak daha çok Anadolu'ya doğru olmak üzere her yöne hızla yayılmıştır. Musul, İsfehan, Nişâbur, Merv, Belh, Herat, Tus, Basra, Amul gibi zamanının önemli bütün şehirlerinde inşa edilen medreseler sayesinde Büyük Selçuklu Devleti'nin Yakındoğu, Mezopotamya ve Anadolu'daki hâkimiyeti oldukça güçlü bir konuma yükselmiştir (Kafesoğlu, 1997: 390).

İslâm eğitimi, Müslüman toplumların kendi iç dinamikleri ve çevreleriyle olan mücadeleleri sırasında meydana gelen birçok siyasal ve toplumsal gelişmeden olumlu ve olumsuz anlamda etkilenmiştir (Danışman, 1955: 89). Daha çok sosyo-kültürel olan bu etkilerin bir uzantısı olarak siyasilerin, kanaat önderlerinin ve halkın beklentilerine göre ilimler, din ve dünya ilimleri olarak temelde iki kategoride ele alınmıştır. Buna göre ilimler, dini ilimler olarak fikıh, tefsir, hadis; dünyevi ilimler olarak, felsefe/kelâm, filoloji/gramer, matematik/riyaziyât, tıp ve astronomi olarak bazı tasnif edilmiştir (Kafesoğlu, 1997: 390). 
Medreselerin kuruluş amaçları göz önüne alındığında ağırlıklı olarak fikıh ve hadis ilmi ile ilgilendiklerini söylemek mümkündür. Çünkü devlet ve toplum düzeninin en önemli unsurlarından olan yarg1 sisteminin işlevselliğini sürdürmesi ve devrin gereksinimlerine göre yeni hukuksal çözümler aranması neticesinde, F1kıh ve Hadis ilimlerine olan ihtiyaç artmıştır. Dolayısıyla Müslüman dünyasının önemli bütün merkezlerinde fikhî mezheplerin görüş ve ilkelerini programlarına konu edinen eğitim yuvaları kurulmuştur (Atay, 1983: 33 vd.).

\section{2- Eğitsel Açıdan Hadis ve Kelam İlmi}

Dini bilginin oluşum ve gelişiminde önemli bir konuma sahip olan Sünnet, büyük oranda Hadis literatürü üzerine bina edilmiştir. İslâmî ilimlerin gelişim aşamaları incelendiğinde, Hadis ilminin gelişiminde şu şekilde bir yol takip edildiği görülebilir. Hadisler, ilk etapta hicri I. asır boyunca ezber ve yazmaya dayalı bir tarzda tespit edilmeye çalışılmış; daha sonra hicri II. ve IV. asırlarda Hadis İlimleri’nin tedvin ve tasnifini tamamlanmıştır (Koçyiğit, 1997: 199-207). Hadis ilmi açısından Altın bir çağ olan hicri III asırda Sahih hadislerin tayin ve tespiti büyük oranda sağlanmıştır. Büyük hadis imamlarının yaşamış olduğu bu çağdan sonra, var olan rivayetlerin farklı metodik şekillerde yeniden ele alınmasından başka bir şey yapılmamıştır (Koçyiğit, 1997: 231).

Hadislerin tedvin ve tasnifini gerekli kılan önemli iki neden vardır. Bunlar, Hadis uydurmacılığının önünü almak ve Hadis ilmine yönelik başını Mu’tezile'nin çektiği kelâmî tenkitlere karşı cevap verebilmektir (Koçyiğit, 1997: 231). Buna göre özellikle Hadis metodolojisi olmak üzere, hadis ilimlerinin gelişmesinde Kelâm ilminin önemli katkılarından bahsetmek gerekir. Çünkü muhaddisler, kelamcıların iddia ve saldırılarına karşı koyarken aynı zamanda kendi sistemlerini de kurmaya başlamışlardı. Esasen aynı durum, Kelam ilmi için de geçerlidir. Her iki disiplinde karşılıklı olarak birbirlerini beslemişlerdir (Koçyiğit, 1989: 94). Kelamcılar akla büyük oranda önem vermelerinin bir sonucu olarak, akıl yürütmeye muhalif olan ayetleri te'vîl, hadisleri ise red ediyorlard1. (Koçyiğit, 1997: 222, 224). Ancak dinin aslı olan nass olmadan da akaidin kurulması mümkün değildi. Bundan dolayı haberi bilginin niteliği, kapsamı ve hüccetliği konusunda Hadisçiler, Fıkıhçılar ve Kelamcılar arasında sayısız münazara gerçekleştirilmiştir. Bu istişare ve bilimsel faaliyetlerin sonucunda, etkileri günümüze değin uzanacak ilmi 
tanımlar ve sınıflandırmalar klasik kaynaklarda müstakil başlıklar olarak yer almıştır (Koçyiğit, 1997: 231).

Hadisler, değişik zamanlarda çeşitli nedenlerle kimi zaman methedilmiş kimi zamanda zemmedilmiştir. Özellikle itikâdî oluşumların teşekkülüyle mezheplerin övgü ve yergi esasına dayalı olarak kendileriyle ve birbirleriyle ilgili Hadis uydurmacılığı yarışına girişmeleri, bu eleştirilerinin sayı ve dozajını da artırmıştır (Koçyiğit, 1997: 148). Siyasi, dini, fikri ve içtimai birçok saik nedeniyle tartışmaların merkezine çekilen hadislerin, sağlıklı bir şekilde değerlendirmesini yapmak gittikçe zorlaşmış ve bu süreç, tarafların taassuba varan tarafgirliklerine neden olmuştur. Bu ayrışmanın bir sonucu olarak farklı zamanlarda gelişen birtakım istenmeyen olayların zuhuru, konunun daha sağlıklı bir şekilde ele alınmasını zorunlu hale getirmiştir. Buna istinaden öncelikle eğitimde bilimsellik ve birliğin sağlanması için eğitim kurumları oluşturulmaya başlandı. Siyasetin ve toplumun ihtiyaç duyduğu yetişmiş eleman ihtiyacını temin için kurulan medreselerin daha çok fikhî mevzuları konu edinmesi, usul ilmine ve hadis ilmine duyulan ihtiyacı artırmıştır (Atay, 1983: 33).

Müslüman toplumlarda eğitimin kurumsallaşması, doğal bir sonuç olarak, bazı hususlarda sabit fikirlerin oluşmasına veya önceden var olan katı yaklaşımların kökleşmesine zemin hazırlamıştır. Geniş hadis literatürünün kurumsallaşma ve ihtisaslaşmayla beraber yeniden ele alınması, hadis ilminde birtakım metodik ilkelerin savunulması neticesini beraberinde getirdi. ${ }^{3} \mathrm{Bu}$ bağlamda, hadislerin amelî ve itikâdî konularda delil olarak kullanım şartları ve hüccetlik bakımından konumlarının ne olduğu konusunda, İslâmî disiplinler arasında görüş farklılıklarının ortaya çıkması doğal karşılanmalıdır. Hadis ilminin gelişim süreci içerisinde usul ilkelerini belirlerken Kelâm ilminden etkilendiği söylenebilir (Koçyiğit, 1997: 231).

İslâm düşünce tarihinde Kelâm ilmi, reye verdiği önemden dolayı her dönemde eleştirilmiştir (Mert, 2001: 205). Bu eleştirilerin merkezini Hadisçilerin başı çektiği selefi yaklaşım olarak görmemiz mümkündür. Nitekim Hadisçiler, Kelam ilmini eleştirmek için dahi konuşmanın onları onaylamak anlamına gelebileceği kaygısını taşımaktadırlar (Koçyiğit, 1989: 256, 258). Kanaatimizce onların bu tutumunda daha önceden akıl (rey)

\footnotetext{
${ }^{3}$ Geniş bilgi için bkz. Hüseyin Kahraman, Hadis Usûlünü Nassa Dayandırma Çabası, Uludağ Üniversitesi, İlâhiyat Fakültesi, c. 10, Sy. 2, 2001, ss. 169-195.
} 
taraftarlarının nakilcilere reva gördükleri zulüm ve baskının sosyo-politik etkileri yatmaktadır. 11. yüzyıldan itibaren, dâhili ve harici muhalif fikri cereyanlara karşı kenarda hazır tutulan bir araç olmaktan başka ilgi görmeyen Kelâm ilmi, 11. yüzyıl öncesinde ise, selefi düşüncenin dışında sapkın bir anlayış ve metod biçimi olarak anlaşılmıştır. Eş’ârî mezhebinin teşekkülüne değin sapkınlık olarak değerlendirilen Kelâmî gayretlerin sonraları Sünnî Kelâm adı altında meşru bir zemin kazandığını söylemek mümkündür. Böylece İslâmi ilimlerin tedvin dönemindeki Mu’tezile, Cebriyye, Kaderiyye, Müşebbihe, Mücessime ve Mürcie gibi ilk dönem Kelâm firkaları ehl-i bidat; Eşarilik ve Maturidilik gibi sonradan teşekkül etmiş Kelâm firkaları, ehl-i sünnet olarak değerlendirilmiştir. Ehl-i Bidat olarak değerlendirilen i’tizali anlayışa sahip kelâmî yaklaşımların hâkim genel düşünce sistemi içerisinde konumlarını kaybederek Şia gibi uç cephelere kaymak zorunda bırakılması başka sorunların doğmasına neden olmuştur (Topaloğlu, 1981: 187-188).

İslâmî ilimlerin tedvin ve tasnifinin tamamlanmasını takiben eğitim sistemine egemen olan Medrese sisteminin başlangıcından itibaren Kelâm ilmine hep kuşku ile bakılmıştır (Mert, 2001: 201). Medrese Ulemasının Kelâm ilmine Felsefe'ye yakınlığından dolayı kuşkuyla bakması, uzun vadede Kelâm ilmi’nin bilimselliğinin ve ilimler içerisindeki yerinin sorgulanmasına neden olmuştur. (Mert, 2001: 194-206). Esasen bu durumun yadırganacak bir tarafı yoktur. Çünkü bahsi geçen dönemlerde, felsefe ile kelâm içselleşerek mecz olmuş durumdaydı (Danışman, 1955: 32). Nitekim İslâmî konular üzerinde düşünsel çaba içerisine girildiğinde Felsefe ve Kelâm'ın birbiriyle dirsek temasına geçmesi kaçınılmaz oluyordu.

Yaygın İslâm düşüncesinde felsefeye ve akla yaklaşımı olumsuz olarak etkileyen siyasi ve toplumsal bazı nedenler mevcuttur. Bu nedenlerin başında, diktatör yönetimlerin başta olduğu dönemlerde devletin hâkim düşüncesi olarak halka dayatılan itizâli düşüncelerin kendilerini aklın savunucuları olarak nitelendirmeleri gösterilebilir. İslâm düşünce tarihine "Mihne Olayları" adı altında kara bir leke olarak geçen bu süreç içerisinde, akli ve nakli bilgiler birbirlerinin alternatifiymiş gibi tarafgirlikle savunulmuş ve Müslüman toplumların kültürel hafızasında tamiri güç hasarlara neden olmuştur (Topaloğlu, 1981: 184; Koçyiğit, 1997: 221, 226-229).

İslam'ın ilk dönemlerinde toplumsal yapının güçlü olmasının da etkisiyle kısa zamanda güçlenen Müslüman siyasal gücü, halk ile idarecilerin zıtlaşması ve bu 
zıtlaşmadan yararlanmak isteyen harici unsurların katılımıyla zayıflamaya başladı. Sonuçta İslâm'ın siyasal birliği parçalandı ve oluşan otorite zafiyetinden farklı birtakım egemen siyasal güçler, tarih sahnesine çıktı. Yeni bu siyasi güçlerin çoğunluğu, henüz Müslüman olmuş Mevâlî unsurlardan oluşuyordu (Turan, 1969: 331-332). Esasen Arapların da tarihin akışı açısından çok uzun sayılamayacak bir öncelikle diğer milletlerden önce Müslüman oldukları göz önünde bulundurulursa, şu yaklaşımı sergilememizde bir sakınca olmadığını düşünebiliriz. Asr-1 Saadet sonrasında Müslüman idarecilerin tamamı, kendi siyasal egemenliklerini sağlamlaştırmada ve diğerleriyle olan siyasal mücadelelerinde üstünlüğü ele geçirmek için dini ve ilmi konuları, çoğunlukla bir araç olarak kullanmışlardır (Akbulut, 2001: 82-106). Kanaatimize göre, İslâm peygamberinin ebediyete irtihalinin hemen ardından başlayıp temelleri asr-1 saadette atılan dini ve ilmi mevzuları siyasete alet etme geleneği, günümüze kadar varlığından hiçbir şey kaybetmeden devam etmektedir.

Siyasal gücün Arap unsurlardan Mevâlî unsurlara geçmeye başladığı bir döneme rastgelen Medrese eğitimi, devrin hâkim güçleri tarafından egemenlik mücadelesinde etkin bir silah olarak kullanılmıştır. Siyasi kaygıların egemen olduğu bir anlayışla düzenlenen Medrese eğitim sistemi, doğal olarak bilimsel yaklaşımlara göre değil, ideolojik yaklaşımlara göre biçimlenmiştir (Kafesoğlu, 1997: 389-390). Bundan dolayı Sünnî İslâm dünyasının koruyuculuğuna soyunan Büyük Selçuklu Devleti'nin Şii devletlerle olan siyasal mücadelesinde Medreseler yoluyla konumunu sağlamlaştırma gayretleri, ilmin siyasallaşmasına neden olmuştur (Kafesoğlu, 1997: 378-379). Kanaatimize göre nakle büyük önem veren Sünnî düşüncesinde aklın fazla itibar görmemesi ve Şii düşüncenin yansıması olarak kabul edilen itizâlî fikirlerin akıldan kaynakladığı düşüncesinden dolayı, özellikle Mezopotamya bölgesinde akla ve aklî ilimlere karşı olumsuz bir yaklaşımın doğmasına neden oldu. Nitekim Büyük Selçuklular, Anadolu Selçukluları ve nihayet Osmanlı Medrese programlarına göz atıldığında, nakle verilen değer rahatlıkla görülebilir. Burada nakilden kasit, Hadis edebiyatından beslenen 'Haber'dir. Bu durumda nakilden beslenen Müslüman eğitim anlayışı, Hadis İlmi’ni önemserken akla göre hüküm veren Kelâm İlmi’ni arka plana attıklarını söylememiz mümkün görünmektedir. Kelâm ilminin Hadis ilmine oranla daha az ilgi görmesinin izdüşümlerini, devrin toplum ve eğitim yapısında görmek mümkündür (Kafesoğlu, 1997: 387). 
Tuğrul b. Mikâil b. Selçuk (ö. 455/1063) devrinde vezirlik yapan Ebû Nasr Muhammed ibn Mansûr (ö.456/1045) Mutezilî fikirlerin etkisinde kalarak, Horasan yöresinde nakilcilere yönelik baskı ve zulüm uygulamıştır. Devlet idaresine getirilen itizal fikri yanlılarının yönetimde uyguladıkları zulmün ve eğitimde başlatmış oldukları baskının boyutları Horasan yöresini aşarak tüm İslam coğrafyasını etkilemiştir (es-Subkî, 1324: II/270). Kanaatimize göre Büyük Selçukluların halifelik makamındaki bu ilk yönetim denemeleri, kendilerinden önceki Arap yöneticilerin sebep olduğu Mihne Olayları'nı hatırlatmaktadır. Nakilciler üzerindeki baskı ve ümmetin tamamına yayılan akı1-nakil zıtlaşması, Tuğrul beyin vefatı ve sonrasında yaşanan taht mücadelesinde galip gelen Alparslan Muhammed b. Dâvûd (ö.465/1072)'un dönemine kadar devam etmiştir. Bu tarihten sonra Arap halife ve Türk sultanları birlikte hareket ederek nakilcilere uygulanan baskıları kaldırmışlar ve İslam dünyasında dinî ve siyâsî birliğin tesisi için, Şii-İtizali birlikteliğine yönelik ilmi-askeri açıdan birçok faaliyete imza atmışlardır. Bu faaliyetlerin bir uzantısı olarak Alparslan'ın veziri olan Ebu Alî el-Hasan et-Tûsî Nizamülmülk (ö.1092) tarafindan inşa ettirilen Nizamiye Medreselerinde, nakli yaklaşıma verilen desteğin bir göstergesi olarak, yalnızca amelde Şâfiî akaidde ise Eş’arî olan âlimlerin ders vermesine müsaade edilmiştir (es-Subkî, 1324: III/90).

Kanaatimizce Ehl-i Sünnet çevrelerinde felsefi düşüncenin, Sünnî düşünce ile olan talihsiz ilişkisinden dolayı, hoş karşılanmıyor olmasına ek olarak, aklî düşüncenin Şia bünyesindeki İslâmî ekollerin düşüncesi olarak lanse edilmesi, Sünnî dünyada felsefi düşünceye ve akla yakınlığıyla tanınan Kelâm İlmi’ne bakış açısını olumsuz yönde etkilediğini söylememiz mümkündür. Nitekim halkın, eğitim kadrolarının ve idarecilerin kısır bir döngü içerisinde birbirini olumsuz yönde etkilemesi, Müslüman toplumlarda aklî ilimlere yönelik menfi bir tutumun doğmasına neden olmuştur. Medrese eğitim sistemi içerisindeki icâzetname anlayışının kişisel amaçlar için kullanımı gibi farklı etkenlerin varlığı dikkate alındığında, hâkim olan bu olumsuz yaklaşımların dışına çıkmanın ne denli güç olduğuna kanaat getirilebilir (Atay, 1983: 159).

İslâm medeniyetinin geçirmiş olduğu bu siyasal, toplumsal ve bilimsel buhrandan etkilenen Hadis ve Kelâm İlmi, üzerlerine kalan bir takım sorunların çözümüyle meşgul olmak zorunda kalmıştır. Bu sorunların başında nakli bilginin niteliği, konuları ve usulü 
gibi mevzular gelmektedir. Bu bağlamda Hadis ve Kelam ilimlerinin ilmî duruşunu belirlemede bilgi kaynağı olarak habere bakış açıları büyük önem arz etmektedir.

\section{3- Epistemolojik Açıdan Hadis ve Kelam İlimlerinde Haber}

İslâmî düşünce için haberin bilgi kaynağı olarak kabul edilmesinin en önemli nedeni, İslâm vahyini temsil eden Kur'an da dâhil İslâmî öğretinin tümüyle haber üzerine inşa edilmiş olmasıdır. Buna göre haberin kabul edilmemesi, aynı zamanda ana kaynağın da reddi anlamına gelecektir (Özcan, 1993: 68).

Haber, sözlükte bir nesneyi gereği gibi bilmek için yoklayıp sınamak, bir şeyin iç yüzünden haberdar olmak manasına gelen hubr veya hıbre kökünden türemiş bir isimdir. Terim olarak ise, geçmişte meydana gelen veya gelecekte vuku bulacak bir olayı bildiren söz, mahiyeti itibariyle doğru veya yanlış olma ihtimali bulunan ifade ve duyularla algılanıp nakledilen söz şeklinde tanımlanmıştır. Her üç tanımdaki ortak nokta, haber konusunun duyularla algılanabilir olmasıdır (İbn Manzûr, ts: 1091; MEB, 1995: II/1088). Arapça bir kelime olan haber, Türkçe'de daha çok bir olay veya olgu üzerinde iletişim vasitalarıyla elde edilmiş bilgi anlamında kullanılır (TDK, 1998: 591).

Kur’ân'da haber kelimesi tekil (en-Neml Sûresi, 27/8; el-Kasas Sûresi, 28/29) ve çoğul (et-Tevbe Sûresi, 9/94; Muhammed Sûresi, 47/31) olarak ikişer ayette geçmektedir. Haber kökünden türemiş olan "hubr" kelimesi ise, masdar olarak iki yerde geçmektedir (el-Kehf Sûresi, 18/68, 91). Esma-i Hüsn’adan olup her şeyin iç yüzünden haberdar olan anlamında haber kelimesinin ism-i faili olan "habîr" kelimesi ise, kırk beş ayette geçmektedir (Abdulbâkî, 1945: 226-227). Haberin tanımı ve ne olduğu konusunda değişik yaklaşımlar mevcuttur. Bazılarına göre haber kendisinde doğruluk veya yalan olma ihtimali olan bir sözdür. Bazılarına göre de haber, bir haber vereni gerektiren sözdür. O, haber verenin bulunmasından dolayı haber adını alır. Şayet, haber veren bulunmasaydı, söze haber adı verilmezdi (el-Cürcânî, 1985: 101-102).

Gerek Kelamcılar için ve gerekse Hadisçiler için haberin ne olduğundan daha çok ne derece gerçeği yansıttı̆ğ önemlidir. Bu nedenle her iki ilim dalına mensup âlimlerce haberin neliği ve kaynağı konusunda birtakım eleştiriler getirilmiştir. Ancak hadisçilerin kendi meslektaşları olan hadis ravilerini cerh etmeleriyle Kelamcıların eleştirileri amaç ve kapsam açısından farklılıklar gösterir (Koçviğit, 1997: 224). 
İlmî olarak haberi bilgi kaynağı kabul etmemek, kişinin kendisini ve içerisinde bulunduğu dünyayı inkâr etmesiyle eş anlamlıdır. Çünkü insan, ismine ve nesebine varıncaya kadar varlığına dair tüm bilgileri ancak haber vasıtasıyla öğrenebilir (elMâtürîdî, ts: 7). Haber ve haberleşmeyi insanı hayvandan ayıran en önemli özellik olarak görmek mümkündür. Çünkü insan haber sayesinde bilinmeyen birçok bilgiye ulaşabilir. Haberi reddetmekle işitilen konuşmaların reddedilmesi aynı şeydir. Bu durumda ilim üretmesi gereken insan ile içgüdülerine göre hareket eden hayvan arasında bir fark kalmaz (en-Nesefî, 2004: I/16).

Haber, Hadis âlimlerine göre, Hz. Peygamberin söz ve davranışlarını aktaran Hadis ile aynı şeydir. Ancak Haber, Hadis'e oranla daha geniş bir naklî bilgiyi içerir (Koçviğit, 1997: 9). Haber peygamberle birlikte sahabe ve tabiûn'dan gelen rivayetleri de içerir. Ancak Hadis, sadece peygambere nispet edilebilir. Yani, haberle hadis arasında içlemkaplam farkı vardır. Bu durumda, "Her hadis haberdir ama her haber, hadis değildir" denilebilir. Bu bağlamda tarih ve benzeri ilimlerle meşgul olanlara Ahbarî denildiği halde, yalnız, Hz. Peygamberden gelen haberlerle uğraşanlara Muhaddis denilir (es-Suyûtî, 1972: $6)$.

Haberin bilgi kaynağı olarak kabul edilmesinin anlamı, ilgili haberin doğru veya yanlış olmasıyla değil, dış dünyada bir ilişkiyi bildirmesiyle ilgilidir. Eğer haberin dış dünyada bir karşılığ 1 varsa doğru haber; yoksa yalan haber olur. Buna göre doğru ve yalan olma haberin değil, habercinin niteliklerinden olur (et-Taftazânî, 1408/1988: 17). Aklın veya duyu organlarının bazen yanıltıcı olabileceği gibi, yalan veya yanlış haber de yanıltıcı olabilir. Şu halde aklın değerlendirme sürecinden geçmediği müddetçe haber, bilgi kaynağı olarak kesin bir niteliğe sahip değildir (es-Sâbûnî, 1969: 29; et-Taftazânî, 1408/1988: 1718). Nitekim vahiyle de haberin niteliğinin gerçeği yansıtıp yansıtmadığı konusunda değerlendirilmesi istenmektedir (el-Hucurât Sûresi, 49/6).

Haberin doğruluğu, gerçeklerle örtüşmesine bağlıdır. Bu bağlamda diğer bilgi kaynaklarında olduğu gibi haberin de zorunlu bilgi ifade etmesi için doğruluğunun ispatlanması gerekir. (Koçyiğit, 1997: 183). Haberin doğruluğu, haberi verenlerin belli bir sayıya ulaşmasına veya haberin bazı nitelikleri taşımasına değil, bir konudaki bilgi açı̆̆ını ve şüpheyi kaldırmasına bağlıdır (el-Mâtürîdî, ts: 9). Bununla birlikte nakledilen haberler arasında gerek tanımlama, gerek sınıflandırma ve gerekse arındırma için sistematik bir 
ayrıma olan ihtiyaç, İslâmî disiplinler arasında ortak bir dilin gelişmesine neden olmuştur (Koçyiğit, 1997: 231).

Tarihsel süreç içerisinde İslâmî disiplinler açısından haber ve nakilden kast olunanın aynı şey olduğunu söylememiz mümkün görünmektedir. Nitekim kelamcıların haberi bilgi kaynakları içerisinde saymak için bu denli ısrarcı olmalarının nedenini, vahyin de haber yoluyla intikal eden bir bilgi olmasında aramak gerekir. (Özcan, 1993: 68). Buna göre delil veya hüccet niteliği olan her haberi nakilden saymamız mümkün görünmektedir. Dolayısıyla doğru haber başlığı altında değerlendirmeye tabi tutulan her konu, nakledilen dini bilgilerin ne derece bağlayıcılığı olduğunun bir açıklaması niteliğindeydi. Aynı durum eğitim sistemi içerisinde verilen Hadis, Fıkıh ve Kelâm dersleri için de söylenebilir. Nitekim her ilim dalı, konu ve ilkelerini belirlerken, nakledilen haberi bilgilerin sıhhat derecesine göre bir yol takip ediyordu (Koçyiğit, 1997: 231).

Kelâmcılara ve hadisçilere göre doğru haber, iki kısımdır. Birincisi, Mütevâtir Haber; ikincisi ise âhad haber veya Peygamberin Haberi'dir. (el-Mâtürîdî, ts:9; el-Cezâirî, 1328/1910: 33). Mütevâtir haber, bilgi değeri ve hükmü açısından zorunlu bilgi; peygamberin haberi ise, delillendirme metoduyla da olsa, kesin bilgi değeri ifade eder (esSâbûnî, 1969: 29; et-Taftazânî, 1408/1988: 17-18). Hadislerin genel olarak mütevatir ve âhad haber olarak taksimi hadis âlimlerince de kabul görmüştür. Hadisçilerin Sahih, Hasen ve Zayıf şeklindeki üçlü tasnifi ise, âhad haberin kısımlarıdır. Onlara göre haberin metin ve senet yönünden tenkidi, ancak âhad haber için söz konusu olabilir (Koçyiğit, 1993: 125). Selefî düşünceye mensup bilginler, ümmetin doğruluğunu benimsemiş olduğu âhad haberlerin manen mütevâtir haber gibi kabul edilerek fikhî ve itikadî meselelerde kesin bir delil olarak kabul edilmelisi taraftarıdırlar (el-Cüveynî, 1369/1950: 359-360). Âhad haberi dinde kesin bir delil olarak kabul edilmesini savunan âlimler, bu kavrama ilișkin eserlerinde özel bölümler ihdas etmişlerdir (Şâfîi, 1996: 359).

Genel olarak haberin mütevatir ve âhad haber olarak taksiminin dışında farklı sınıflandırmalara da rastlamak mümkündür. Bunlardan biri olan Meşhur veya Müstefiz Haber, mütevâtir ve âhad haber arasında orta bir yol izleme eğilimindedir. Ancak meşhur haber, bilgiyi ve ameli gerektirdiğinden tevatür seviyesindeki bilgi olmakla beraber, akıl yürütme ile kazanılmış nazari bir bilgi olduğu için tevatürden ayrılır. Dolayısıyla meşhur haberin kendi içerisinde değișik çeşitlerinin olması dikkate alınacak olursa, mütevatir ve âhad haber ayrımından dışında çok farklı bir açılım olduğu söylenemez (el-Bağdâdî, 1416- 
1995: 325 vd.). Esasen meşhur haber, çok rivayet edildiğinden dolayı tevatür seviyesine çıkarılmış âhad haber olarak da tanımlanmaktadır (Koçyiğit, 1993: 124-125).

Âhad habere bakış açılarındaki farklılıktan dolayı hadisçiler ve kelâmcılar arasındaki sıfatullah, ru'yetullah, teşbih, tecsim, ahiret halleri gibi birçok tartışmalı mevzu vardır (Koçyiğit, 1989: 112-220; 1997: 189). Muhaddisûn ve mutekelimûn arasında devam eden haberlerin delil olarak kabul edilme nitelikleri hakkındaki münâzalarda bir hususun dikkatlerden kaçmaması gerekir. Âhad haberle gelen bilginin reddedilmesinin anlamı, ilgili sözü söyleyenin peygamber de olsa yanlış bilgi içerdiği söylemek değil, ilgili sözün peygambere isnadının reddedilmesi demektir. Nitekim âhad haberlerin doğru ve uydurma olma ihtimalinin mevcudiyeti ve mütevâtir seviyesine ulaşmış haberlerin sayısının ise yok denecek kadar az olması (Subhî, 1981: 118), Kelâmcilar arasında âhad haberin sadece zanni bir delil teşkil edebileceğini; zanni delilin ise, akaid konularında tek başına yeterli olamayacağı fikrinin yerleşmesine neden olmuştur (el-Cürcânî, 1985: 96, 97). Kelamcıların zanni delil teşkil ettiği için akaidde âhad haberlerin delil teşkil edemeyeceği (Atay, 1992: 139, 140) iddialarına cevaben hadisçiler, âhad haberlerin kesin delil olduğunun kanıtı olarak onların icma seviyesinde kabul edilmesini ileri sürerler (Koçyiğit, 1989: 246).

Sünnî kelâm düşüncesinde genel olarak Kur'an'a aykırı bilgiler ve hükümler içeren âhad haberlerin peygambere isnadı konusunda ihtiyatlı davranılır. Çünkü peygamberin vahye ve akla aykırı bir beyanda bulunması düşünülemez. Bu bağlamda vahye ve akla uygun olmayan âhad rivayetleri kabul etmemek, bu haberlerin peygambere isnadını kabul etmemek anlamına gelir (Ebû Hanîfe, 1981:32,33). Dolayısıyla âhad haber, mütevâtir gibi kesin bir bilgi doğurmaz. Ancak âhad haberin vahye uygunluğu ve râvi güvenilirliği gibi hususlarda bir sıkıntı yoksa zanni bir delil olarak onunla amel edilebilir (el-Mâtürîdî, ts:89).

Haberlerin tevatürlük derecelerine göre taksimi ve bu taksim içerisinde, mütevatir olan haberlerin önemine ilk vurgu yapanlar, Kelâmcılar olmuştur. Hadisçilerin sisteminde çok dikkat çekmeyen haberin tevatürlüğü meselesi, sonraki dönemlerde kelâmcıların iddialarına cevap sadedinde gündeme gelmiş ve belli bir noktadan sonra hadis sistematiğinde yerini almıştır (Koçyiğit, 1997: 230-231). Hadisçilerin âhad haberin tevatürlüğüne ve bilgi değerine yönelik kelâmcılardan ayrı olarak alternatif açıklama girişimleri bireysel ve sınırlı ölçüde kalmıştır (Koçyiğit, 1997: 183). 
Kur'ân'da, zannın kesin bilgi ifade etmeyeceği (en-Necm Sûresi, 53/28), önceki nesillerin bilgileri de dâhil (el-Mâide Sûresi, 5/104), hakkında bir bilgi olunmayan meselelerin peşine düşülmemesi gerektiği (el-İsrâ Sûresi, 17/36) ve bir haber alındığ1 zaman onun doğru olup olmadığının araştırılması (el-Hucurât Sûresi, 49/6) yönündeki önerilerin varlığı, Mu’tezili âlimleri ahad haberlerin kesin bir bilgi kaynağı olamayacağı düşüncesine sürüklemiştir (Koçviğit, 1997: 222-224). İnanç meselelerinde tevâtür derecesine ulaşmış bir hadisin olmadığı halde sonradan kelâmcıların, hadisçilerin baskısı altında bazı hadisleri inanç meselelerine aldıklarına ve buna da manevi tevâtür demek zorunda kaldıklarına tanık olmaktayız. Kelâmcıların meşhur veya manen mütevatir dedikleri bu hadisler, gerçekte hadisçilerin âhad haber dedikleri haberlerden başkası değildir. Aynı şekilde zayıf ve uydurma hadislerin de ilk kelamcıların kaidelerine aykırı olarak sonraki kelam kitaplarına dâhil edildiği görülebilir (Atay,1992: 139, 140). Bu meyanda kabir azabı, münker-nekir, havz, şefaat, muvahhidlerin cehennem azabından kurtarılmaları ve ru'yetullah gibi inanç ile ilgili bazı konular Ehl-i Sünnet mezheplerinde iman edilmesi gereken zorunlu akaid konuları içerisinde sayılmıştır. Bunların hepsi de âhad yolla gelmiş hadislere dayanmaktadır (Koçviğit, 1997: 189).

\section{Sonuç}

İslâmî ilimlerin nakledilen bilgi üzerine dayalı olması ve aklî ilimlerin bu çerçevede faaliyet göstermesi gerektiği düşüncesi, medreselerde bilginin kaynağı olarak habere bakış açısını belirleyen başlıca unsur olmuştur. Akıl-vahiy ve rey-nass gibi başlıklar altında genelleştirilen tartışmaların, aklî ve naklî ilimlerin birbiriyle olan ilişkilerinde olumsuz etkileşime neden olduğu bilinen bir husustur. Ancak bu etkileşim sanıldığı gibi bütünüyle menfi sonuçlara neden olmamıştır. Nitekim ilgili bilim dallarının birbirlerinin aşırılıklarını dengeleyen ve açmazlarını tamamlayan bu münazaralar sayesinde, İslâmî ilimlerde zenginleşme ve gelişme görülmüştür.

İslâmî ilimler arasındaki akıl ve nakil tartışmalarında farklı iki uç noktayı temsil eden veya bu şekilde lanse edilen hadis ve kelâm ilimlerinin konuya yaklaşımlarını belirleyen ana etken, bilgi kaynağı olarak habere ve haberin bilgi değerine atfettikleri değerdir. Bilgi kaynağı olarak genelde haberin, özelde hadisin konumu üzerinde durulmaksızın Muhaddisûn-Mütekellimûn anlaşmazlığının nedenlerini tespit etmek olası görünmemektedir. 
Kelâm ve hadis ilimlerini bir dünya medeniyeti olma iddiasıyla kendini takdim eden İslâmî öğretinin farklı açılardan kendini ifade etme biçimleri olarak görmek mümkündür. Kelâm ilmi, Müslüman toplumun sahip olduğu inançların felsefesini yaparak dıştaki şer odaklarına karşı onun savunuculuğuna ve propagandacılığına giriştiği için evrensel bir dil olan mantık kurallarını ön plana çıkarması gayet doğaldır. Nakli ilimler sınıflandırmasının dışında tutulmaya çalışılan kelâm ilminden farklı olarak hadis ilmi ise, Müslüman toplumun yaşayışında önemli bir konuma sahip Sünnet'in tespit ve tesisiyle ilgilenen nakli bir ilimdir. Bundan dolayı yapıları gereği kelâm ilmi toplumun dıştaki hedeflerini gözeten siyasal bir yaklaşıma, hadis ilmi ise toplumun içteki hedeflerini gözeten sosyal bir yaklaşıma sahip olmuştur. Onların amaç ve araçlarındaki farklılı̆̆ın bir devamı olarak geliştirmiş oldukları metotlarının çeşitliliği de yadırganmamalıdır. Çünkü kelâm ilminin temel çalışma alanı Kur'an iken, hadis ilmininki Sünnet’tir.

Hadisçiler ve kelâmcılar tarafından haberin mütevatir ve âhad olarak genel iki başlık altında toplanması, bizlere konu üzerinde değerlendirme yaparken daha sistemli sonuçlara ulaşma olanağı tanımaktadır. $\mathrm{Bu}$ bağlamda, mütevâtirlik şartlarını taşıyan haberlere ulaşmanın güçlüğü ile âhad haberlerin yanlı ve yanlış olma ihtimali, Kur'an'dan başka kesin delil teşkil edebilecek bir haberin olamayacağı düşüncesini desteklemektedir. Haberlerin hata yapma ve yalan söyleme ihtimalinin bulunduğu insan faktörüne bağl1 olarak aktarılması, onların ancak sistematik bir değerlendirmeden geçtikten sonra bilgi ifade edebilecekleri sonucunu doğurmuştur. Bu bağlamda doğru haberin ilkelerini belirleme işlevini akla vermekten başka çözüm yolu kalmamaktadır. Haberler, ancak aklın önceliğinde bazı unsurlar gözetilerek bir değerlendirme sürecinden geçtikten sonra delil olma niteliğini kazanabilirler. Aklın bu işlevi nasıl yapacağı konusunda ise hadis ve kelâm ilimlerinin birbirleriyle dirsek teması içerisinde çalışmaları gerekir.

\section{Kaynakça}

Abdulbâkî, M. F. (1945). el-Mu'cemu'l Müfehres li'l Elfâzı'l Kur'âni'l Kerîm. Mısır: Dâru'l-Kutubi’l-Misriyye.

Akbulut, A. (2001). Sahabe Dönemi İktidar Kavgası, Ankara: Pozitif.

Atay, H. (1992). İslam'ın İnanç Esasları. Ankara: Ankara Unv.. 
Atay, H. (1983). Osmanlılarda Yüksek Din Eğitimi. Ankara: Dergah Yay.

el-Bağdâdî, A.M. (1416-1995). el-Fark beyne'l Fırak. (Thk. M.M. Abdulhamîd). Beyrût: el-Mektebetü’l-Asriyye.

Topaloğlu, B. (1981). Kelam İlmine Giriş. İstanbul: Damla Yayınevi.

el-Buhârî, M. I. (1400). el-Câmiu’s Sahîh. Thk. M. el-Hatîb, M.F. Abdulbâkî). Kâhire: Matbaatu’s-Selefiyye.

el-Cezâirî, T. A. (1328/1910). Tevcihu’-Nazârilâ Usûli’l-Eser. Misır.

el-Cürcânî, A. Ş. (1985). Kitâbu’t-Ta’rîfât. Beyrût: Mekteb Lübnân.

el-Cüveynî, A. (1369/1950). Kitâbu'l İrşâd. (Thk. M. Mûsa ve A.A. Abdulhamîd). Bağdat: el-Mektebu’l-Hancî.

Çelebi, A. (1983). İslam'da Ĕgitim Öğretim Tarihi. (Çev. A. Yardım). İstanbul: Damla Yayınları.

Danışman, N. (1955). Kelâm Illmine Giriş. Ankara: Ankara Ünv. Basımevi.

Ebû Dâvud, S. (ts). Sünenü Ebû Dâvud. Nşr. M.N. el-Elbânî. Riyad: Mektebetu’l-Me‘ârif.

Ebû Hanife, N. (1981). İmam-ı Azam'ın Beş Eseri. (Çev. M. Öz). İstanbul: Kalem.

Elmalı1ı, H. Y. (1979). Hak Dili Kur'ân Dili. İstanbul: Eser Neşriyat.

İbn Manzûr. (ts). (Nşr. A. A. el-Kebîr, M.A. Hasebullah, H.M. Şâzilî), Lisânu'l Arab. Kâhire: Dâru’l-Maârif.

İbn Sa'd, M.Z. (ts). et-Tabakâtü'l Kübrâ. (Nşr. İ. Abbas). Beyrût:

Kafesoğlu, İ. (1997). Türk Milli Kültürü. İstanbul: Ötüken Yy.

Koçyiğit, T. (1989). Hadisciler ve Kelâmcılar Arasındaki Münakaşalar, Ankara: TDK.

Koçyiğit, T. (1993). Hadis Usûlu. Ankara: Ankara Ünv. Basımevi.

Koçyiğit, T. (1997). Hadis Tarihi. Ankara: TDK.

el-Kurtûbî, A. B. (1427/2006). el-Câmi' li Ahkâmi'l-Kur'ân ve'l-Mübeyyinü Lemâ Tezammenehu mine'l Sünnet ve Âyi'l-Furkân. (Thk. A.A. el-Turkî). Beyrût: Müessesetü’rRisâle. 
el-Mâtürîdî, M. (ts). Kitâbu’t-Tevhid. (Thk. F. Huleyf). İskenderiye: Dâru’l-Câmiatu’lMisriyye.

Mert, M. (2001). Kelâm İlmi'nin Zemmi Üzerine Bir Araştırma. Journal of Islamic Research. c.14, sy.1. Ankara.

Milli Eğitim Bakanlığı. (1995). Örnekleriyle Türkçe Sözlük. Ankara: MEB.

en-Nesefî, M. (2004). Tabsıratu'l-Edille fi Usûli’d Dîn. (Nşr. H. Atay). Ankara: TDK.

Özcan, H. (1993). Mâtürîdî’de Bilgi Problemi. İstanbul: Marmara Unv.

el-İsfehânî, M. R. (ts). el-Müfredât Elfâzi’l Kur'ân, (Thk. M.S. Keylânî). Beyrût: Dâru'lMa’rife.

es-Sâbûnî, N. (1969). el-Bidâye fî Usûli'd-Dîn. (Thk. F. Huleyf). İskenderiye: Dâru'lMeârif Bimısr.

Subhî, S. (1981). (Çev. Y. Kandemir). Hadis İlimleri ve Istılahları. Ankara.

es-Subkî, T. N. (1324). Tabakâtuş-Şafiyye el-Kübrâ. Mısır.

es-Suyûtî, C.B. (1972). Tedrîbu'r-Râvî fî Şerhi Takrîbi'n-Nevevî. (Nşr. A.Abdullatif). Kâhire:

Şâfîi, İ. (1996). er-Risâle. (Çev. A. Şener, İ. Çalışkan). Ankara: TDV.

et-Taftazânî, M. S. Şerhu'l Akâidi'n-Nesefî. (1408/1988). (Thk. A.H. Sekkâ). Kâhire: Mektebetu’l-Külliyetü’l-Ezheriyye.

Türk Dil Kurumu (1998). Türkçe Sözlük. Ankara: TDK.

Türkiye Diyanet Vakfi (1998). İslâm Ansiklopedisi. İstanbul: TDV.

Turan, O. (1969). Selçuklular Tarihi ve Türk-İslâm Medeniyeti. İstanbul: Turan Neşriyat. 